\title{
Construction features of the historical architecture in the sea port city of Valparaiso: architect E.O.F. Harrington's brick masonry buildings
}

\section{Características constructivas de la arquitectura histórica en la ciudad portuaria de Valparaíso: Edificios de albañilería de ladrillo del arquitecto E.O.F. Harrington}

Marcela Hurtado (Main and Contact Author)

Universidad Técnica Federico Santa María, Departamento de Arquitectura, Valparaiso, Chile Avenida España 1680, Valparaiso, Chile, +56 322654008

marcela.hurtado@usm.cl

\section{Manuel Salazar Santander}

Universidad Técnica Federico Santa María, Departamento de Arquitectura, Valparaiso, Chile manuel.salazar@alumnos.usm.cl

\section{Gonzalo Muñoz}

Universidad Técnica Federico Santa María, Departamento de Arquitectura, Valparaiso, Chile gonzalo.munozv@usm.cl

Manuscript Code: 554

Date of Acceptance/Reception: 03.05.2016/26.11.2014

\begin{abstract}
This research aims to contribute to the field of construction history in Chile, specifically in the seaport city of Valparaiso, in the period between the late nineteenth and early twentieth centuries, which was a time of great economic and urban development. The work of Esteban Orlando Harrington - a renowned Chilean engineer and architect who designed more than 20 buildings (mostly masonry structures) in the Valparaiso portwas studied. This type of construction is analyzed according to the materials, building systems, and structural criteria used. A review is carried out on historic information and documents, and an inspection of five buildings with the goal of understanding how they were constructively conceived is done. Here the most significant case is presented for its architectural, historical, and structural characteristics and values: the former Royal Hotel. The results of this research reveal aspects of Valparaiso's construction history through the work of a professional who adapted foreign techniques to local conditions, with results that are valued for their architectural quality and good seismic behavior.
\end{abstract}

Keywords: History of construction; architecture in seismic zones; brick masonry; Valparaíso; construction industry.

Resumen

La presente investigación tiene como objetivo aportar al campo de la historia constructiva y técnica de la arquitectura del puerto de Valparaíso en el periodo comprendido entre finales del siglo XIX y principios del Siglo XX. Se estudia la obra del reconocido arquitecto - ingeniero Esteban Orlando Harrington quien diseña y construye más de 20 edificios, muchos de ellos en albañilería de ladrillo. Se analiza esta tipología constructiva desde la caracterización de los materiales empleados, los criterios estructurales y un detallado levantamiento del sistema constructivo utilizado. De esta aproximación se desprenden atributos del sistema replicado, y presumiblemente mejorado, por el arquitecto - ingeniero Harrington que ha condicionado su permanencia en el tiempo, en una zona de fuerte actividad sísmica.

Valparaiso's historic buildings are an interesting testimony to the application of architectural technique advances throughout history. It is essential for several reasons for us to discover how buildings with historical, architectural, and urban values were built. This knowledge allows for technical assessment of a given building, contributes to the history of the building's construction, and provides valuable intervention in work materials. In Chile, scarce information is available on the technical and constructional features of historic buildings. Most studies focus on historical or architectural aspects of buildings, without delving into how they were built. In the case of Chile, coinciding with times of economic boom and growth of cities there was intense contact abroad, influencing both architectural and technical aspects of buildings. These buildings also represent the spirit of an era, characterized in this case by the desire to integrate technical advances in other fields-particularly industrial construction. 


\section{Valparaíso between Centuries}

The port city of Valparaiso is an interesting example of a Chilean urban centre that reached an important development in the first decades of the twentieth century. The city witnessed pioneering Chilean technological advances such as gas street lighting and use of trams (Ugarte, 1910). The city's intense trade and economic activities attracted many foreigners who took up residence in Valparaiso, shifting their customs and culture. Valparaiso also maintained frequent relations with the main ports of Europe and North America, where all kinds of goods were imported. This economic boom is also reflected in architecture, both public and private, including beautiful palaces, mansions, and commercial buildings built at the time, which adopted foreign influences.

As Valparaiso's population grows, it becomes one of the most important centres of trade in South America, which is reflected in its infrastructure and the modernization of its institutions. This period is recognized and valued as an early globalization (Consejo de Monumentos Nacionales, 2001), with obvious consequences on the urban image. Professionals from different countries start to come to Valparaiso, either hired by the State or attracted by the opportunities the city offers. Among these, architects, constructors, and engineers leave their mark on the local architecture. Two of the most common types of construction in this period are masonry brick (unreinforced) and balloom frame, both of which are widely used abroad.

It is important to mention particular topographical features of the city: a flat area (called El Plan) surrounded by several hills facing the Pacific Ocean. Urban growth through the centuries has had to work around the problem of low flat areas surrounded by steep hillsides. An important incident in the history of urbanism and construction in Valparaiso was the earthquake of August 6, 1906. This event (a 7.9 on the Richter scale) caused widespread destruction in the city, especially in a flat area called Almendral. There are numerous graphs and written records on the damage to the buildings, including descriptions of the features of construction, in addition to hypotheses on the cause of the collapses (Figure 1). Determinant factors include the lack of reinforcement perpendicular to the facades, the use of masonry untethered, a lack of rigid diaphragms, excessive weight and weight structure cornices, and other decorative elements (Henriquez, 1907). We affirm that this constitutes an inflection point in the city's construction history because it forced architects to rethink how to build more solidly while using the same materials (brick, especially).

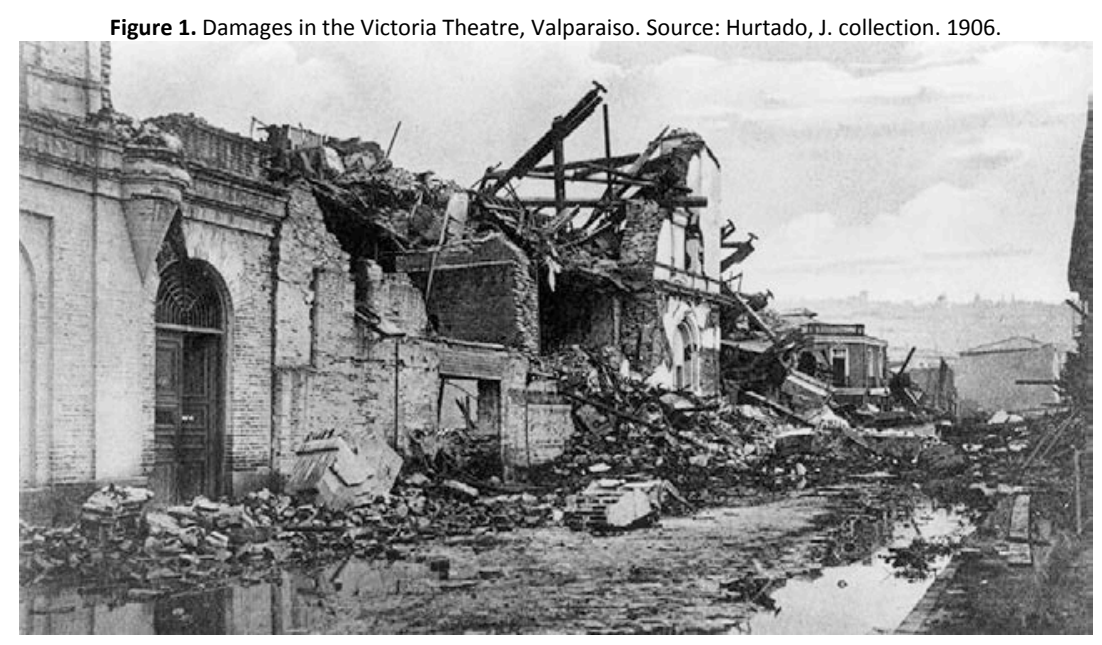

In this context, the work of renowned Chilean engineer-architect Esteban Orlando Harrington (1863-1936) is interesting because at least five of his examined buildings built before the 1906 earthquake did not suffer significant damage. Moreover, these buildings have withstood earthquakes in 1965, 1972, 1985, and 2010 as well. There is no evidence that these buildings have undergone significant structural reinforcements. It is therefore interesting to learn how they were designed. It should be noted, however, that these buildings are not located in critical soil areas, an aspect that will be discussed in the analysis of this specific case.

\section{Influence within Construction Industry}


During the late nineteenth century and early twentieth century, a significant advance in the construction industry took place, mainly fueled by global socioeconomic and industrial progress, impacting Valparaiso. Architecture was influenced by the industrialization and introduced new materials and established building systems to improve the city's buildings (Silva, 1910). In this way, the architecture of the time reacted to the demand for growing construction in the country. Perhaps the best example of adaptation between technology and city demands was the design and construction of elevators to connect the low part of the city with the buildings in the hills. A review of the characteristics and origins of the materials implemented in these buildings will be done to contribute knowledge and comprehensive characterization to these historic buildings.

Despite the large number of constructions carried out in this period, there is scarce research linking economic prosperity, foreign influence, and building technologies. The work presented in detail is shown from this point of view, leaving aside the valuable stylistic analysis. Beyond the contribution to the history of the building, learning how buildings are constructed is crucial for projects of restoration or maintenance (Chavez and Alvarez, 2005). In the case of Valparaiso, its historic centre is on UNESCO's World Heritage List, which reaffirms the importance of this study.

\section{Methodology}

In this research, the buildings themselves are the primary documents. There is a lack of historical resources, such as drawings or other documents, related to the construction of these buildings. The current condition of the building as well as the possibility for inspection of the building allow for a thorough gathering of ground information. This investigation is complemented by an extensive historical analysis of the construction industry in Valparaiso's period of urban development. The study works with different bibliographic materials, plus archives of newspapers and magazines that have provided valuable information. The analysis focuses on the characteristics of materials, structural criteria, and the building setting in the city. Historical research includes the large number of photographs and lengthy descriptions of the effects of the 1906 earthquake in Valparaiso, which provides a fairly accurately approach to the construction types used at that time. This information also establishes which areas of the city sustained the most damage.

\section{Case Study: The Work of Architect E.O.F. Harrington in Valparaiso}

The analysis of a representative exponent of civil and commercial architecture of the time (the Royal Hotel) in connection with an architectural style and construction industry in Valparaiso will be discussed in detail. The building designed by engineer-architect Esteban Orlando Harrington is an exemplary case for several reasons: it is built before the earthquake of 1906, it represents an architectural typology of this time period in Valparaiso, and it has great architectural and constructive value (Wasiberg, 1988). As noted, this building is valued for its stability during the earthquakes in 1906, 1985, and 2010 without having any structural reinforcements.

\section{Localization and Soil Type}

The Royal Hotel is located in the historic quartier of Valparaiso, near the base of Concepcion Hill. This site corresponds to an extension created by dynamiting part of the hill, which then filled over into the sea (Vásquez, 1999). The soil is composed of natural filler, artificial filler, sand, and old rock beach (Vergara, 2010). This composition directly affects the seismic behavior of buildings. Figure 2 indicates Valparaiso's soil types and their relationship with the seismic amplification of the earthquakes of 1906 and 1985. It is shown that the Almendral (flat area) is the most vulnerable, coinciding with sandy soil, and the hills where the soil is rock are the least vulnerable. According to Saragoni and Carvajal (1989), the microzonation they did was based on the damage done by the 1906 and 1985 earthquakes, during which the highest intensity occurred in the district of Hontaneda and the historic area filling, followed by Barrio Puerto, Almendral, and with lesser intensity in the hills. The former Royal Hotel is located on relatively safe ground (zone 2) compared with the ground in the coastal area (zone 1) containing artificial filler. This also implies that the seismic intensity is lower in zone 2 than in the zones containing artificial fill, thus supporting the building's resistance to earthquake damage. This should be taken into account when assessing any historical building's reaction to seismic waves, along with the building's condition and morphological and structural characteristics. 


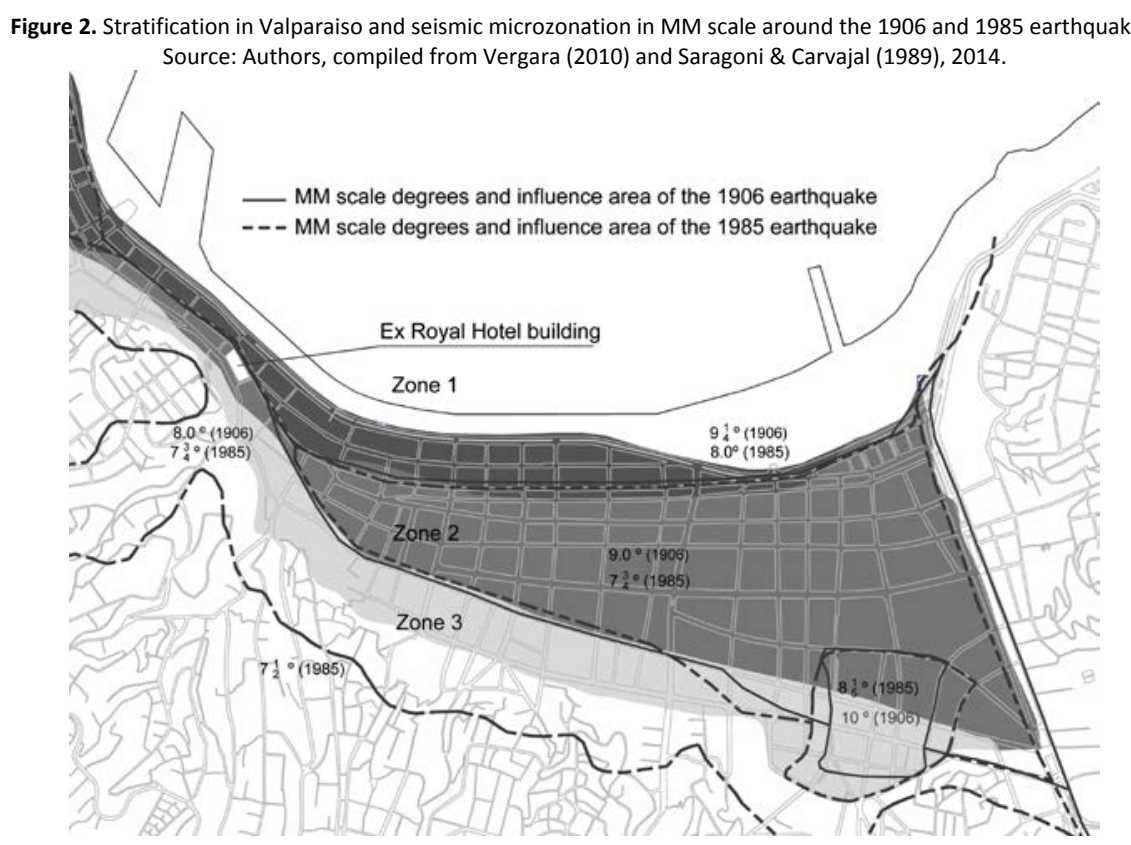

\section{History and Morphologic Features of the Building}

The Royal Hotel was built on the site where the France Hotel previously stood. This was a wooden structure built in 1883 and destroyed by fire in 1894. From this disaster, only the stone foundations remained, which were reused by Harrington for the Royal Hotel's construction. The hotel was built in 1899 and was owned by a wealthy merchant family of Valparaiso. The quality, size, and equipment used in the making of the hotel made it one of the most luxurious structures on the Pacific Coast (León, 2008).

Regarding architectural shape, on the ground checked, the former Royal Hotel is of a regular compact volume with a trapezoidal layout; its major base is $84 \mathrm{~m}$, and the shortest base is $73 \mathrm{~m}$; the building has an average width of 28 meters, and its height is approximately $21 \mathrm{~m}$. It occupies a plot with three facades and has three continuous walls, each facing streets. The fourth firewall facade borders another building, which was built around 1970 (Figure 3). Five transverse axes defining a space approximately $13 \mathrm{~m}$ wide and $28 \mathrm{~m}$ long divide the inside of the hotel, and a fifth section is $24.5 \mathrm{~m}$ wide. The hotel has three floors, each with an average height of $4.3 \mathrm{~m}$; it also has an attic and a basement (Figure 4). In terms of occupation, the first floor is commercial and the upper floors are residential.

Figure 3. Plan of the underground, first floor and roof of the ex-Hotel Royal. Source: Authors, 2014.
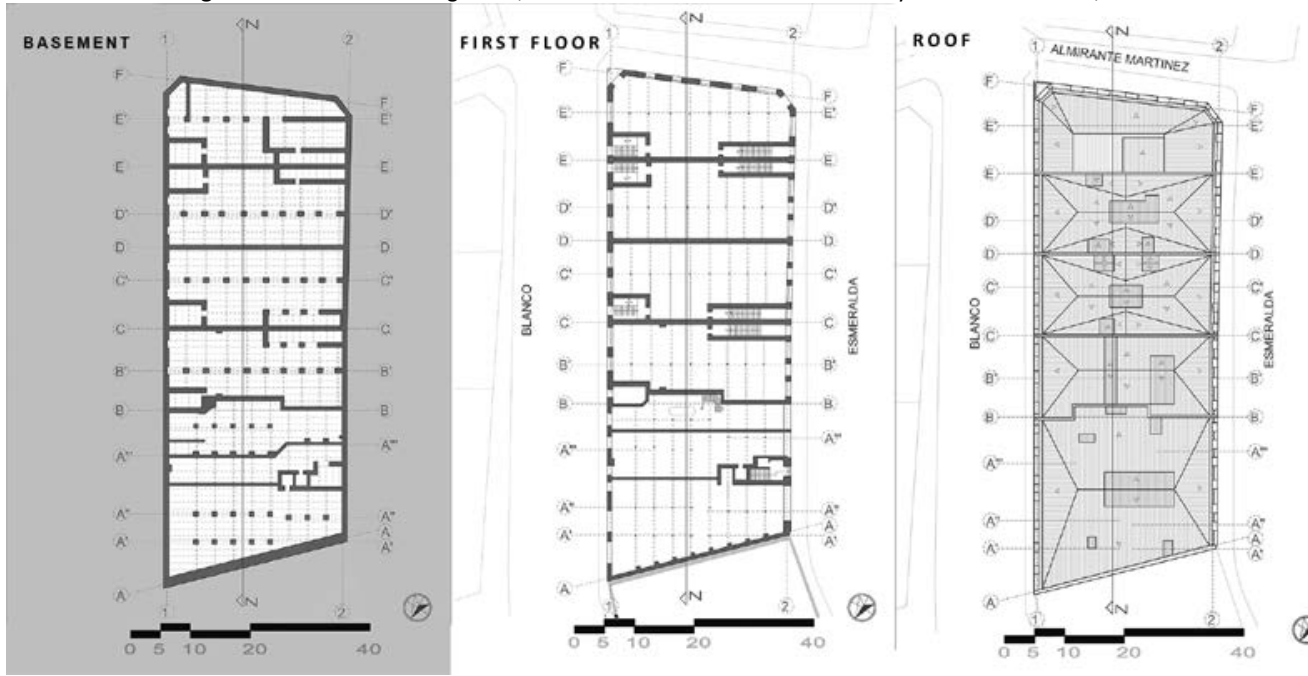


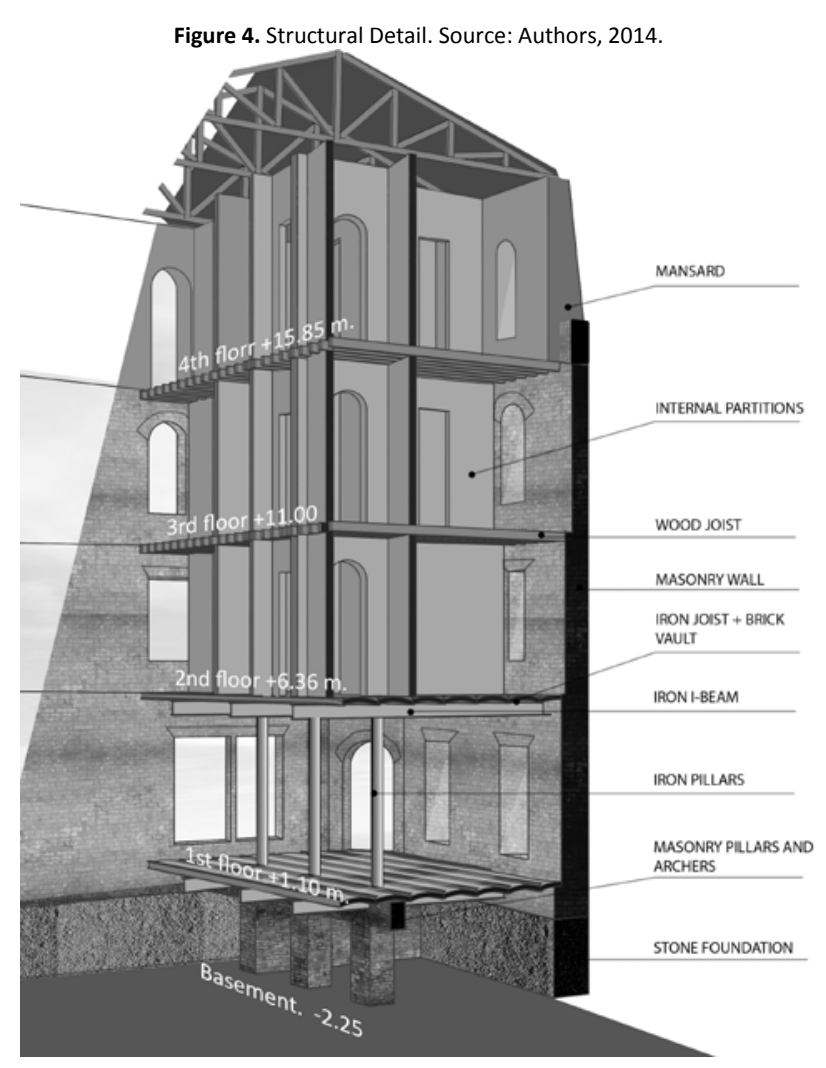

\section{Constructive Typologies}

The two recurring constructive typologies in the studied period in Valparaiso were masonry and balloom, or platform frame. There are a variety of cases confirming the popularity of these European and North American construction methods in other Chilean and Latin American ports. The construction also reveals an early globalization associated with strong commercial activity, which was considers strategic. In Valparaiso, the ballom and platform frame methods were widely used in homes, especially in the hills. This was probably due to the ease of adaptation to the topography of the city. Brick masonry, on the other hand, was used for commercial and public buildings within the flat area of the city. Royal Hotel is an example of this second type: it is a public building, located in the lower area of the city, built in masonry. In addition, this building, like many others in the area, set an almost complete block, giving it importance and a remarkable urban value.

\section{Materials Employed}

As for the supply of materials, the construction industry relied on both domestic production and imports of foreign products. According to data from the Customs of Valparaiso, in 1886 the main supply countries are, listed in order of importance, as follows: Britain, Germany, Argentina, the USA, Peru, and France (SOFOFA, 1896).

\section{Iron}

Data from the Valparaiso Customs confirm that the iron beams and columns were imported mainly from Germany and Britain. L-shaped and round-bar section angle iron was $100 \%$ imported from abroad until 1886 . Since then, the Chilean government has approved the right of free admission of crude L-shaped, $\mathrm{T}$-shaped, and double T-shaped iron beams (Greve, 1944). In 1914, I-shaped, L-shaped, and shaped channel beams were still being imported, as were round bars and cut nails. In Chile, there was no large-scale production of these pieces of iron due to the lack of specialized machinery. These products carry a registered name of the industry in which they were produced, together with its type section. These parts are observed in two of Chilean architect Esteban Harrington's buildings in Valparaiso. The iron pieces are from two German industries: Roechling and Burbach Iron \& Steel Works. 


\section{Brick}

In 1896, the city of Valparaiso boomed with brickwork. The production of bricks emerged along with other plants such as compressed tiles and marble, as well as the production of tar. In 1896, there were 25 brick and tile factories in Valparaiso (Fagalde, 2011). In 1906, brick was still being crafted around the area. The clay was obtained in the same area where the factory was located. There is no record of any quality control, either in the obtaining of raw materials or in the manufacturing process. This lack of control was widely criticized (Henriquez, 1907), especially after the 1906 earthquake destroyed countless brick buildings in Valparaiso. The poor quality of raw materials and lacking control of drying, coupled with poor soil quality, diminished the brick manufacturing process. Similarly, the inclusion of an organic material called "guano" was also criticized because of the assumption of increased salinity and water-binding capacity in the manufactured brick (Greve, 1944).

\section{Wood}

Most woods used for the construction of the buildings were oak, Douglas fir (also known as Oregon pine), raulí, and poplar. Some of the wood was obtained within the country, and others came from abroad, such as the pine and mahogany from Oregon, which were imported by commercial means. The oak was initially used in the central area around the mid-nineteenth century. It came from different places in southern Chile, such as Chillán, San Carlos, Valdivia, and Chiloé forest. The oak was then sent to the central area by sea or railway, where it was sized. In addition, Valparaíso received Vichuquén Oak Canyon and Tinguiririca (Greve, 1944). As for Douglas fir, this was taken to Valparaiso by sea because it was imported from Oregon in the northern United States as well as from Canada. This wood was introduced to the country in the form of boards, planks, beams, and pillars (Greve, 1944). In 1915 in Valparaiso, some of the most renowned timber importers were Compton \& Co., which imported pine raw and processed Oregon ash, American oak, American white pine, red cedar, mahogany, hickory Central, and guayacán; the National Society of ships and timber, which imported Oregon pine, oak, ash and American white pine, cedar, and mahogany from Central America (transported in their own rail cars and ships) working with national woods like raulí, beech, laurel, luma, pellin, olivillo, and guaitecas cypress; and the Society Barraca "El Laja,", which worked with raulí, lingue, laurel, oak, and American elm (Fagalde, 2011). According to Miranda (1903), the most expensive was the Oregon pine wood (which was mainly used in tall buildings because of its resistance), followed by oak, evergreen beech, laurel, lingual, and poplar.

\section{Stone}

Records from 1886 do not mention quarries in the province of Valparaiso, so the stone used for construction was probably obtained from Santiago or provinces in the Aconcagua Valley. As for stone cutting, the most important quarries were owned by Teoblado Brignoli and Juan Ceppi (SOFOFA, 1896). Santiago quarries are in Cerro Blanco, where white stone was mined. The blue or red stone was quarried from the upper side of Cerro San Cristobal. Some pieces were sharpened in the same workplace, such as blocks; others came dimensioned directly from the factory, such as thresholds and bases (Greve, 1944). In the province of Aconcagua, the "Quarries Manufacturer Society of Marble, Stone and Granite Aconcagua" was dedicated to extract these materials within the city Panquehue. In 1889, two Valparaiso quarries were identified to show unstable activity. One is located in the gorge of San Agustin on the property of Juan Reyes, and the other is located in the path of Santiago against the Black Bridge (La Unión, 1899). An exceptional case is the use of temporary quarries for the construction of large buildings. For example, to extend the port of Valparaiso, Pearson industry installed a granite quarry in the Salinas de Viña del Mar. Finally, data from SOFOFA (1896) show an existing workforce related to the field of construction (nearly 17\%). In addition, these documents indicate that the workforce was not necessarily composed of skilled workers, which explains the poor quality of many design characteristics (Henriquez, 1907; SOFOFA, 1896).

\section{Cement, Lime, and Sand}

Lime, like stone, was not produced in Valparaiso. It was brought from places such as Calera de Tango, Polpaico Hill, Lo Prado, and Lo Aguirre. These lime kilns supplied principally the city and its surroundings, excluding distant regions due to the high cost of material transport by train. As for cement, according to Greve (1944), the first load of Roman cement was probably introduced to Valparaiso by an English ship belonging to Loring \& Co. in 1867. This cement importing remained active until cement factories were built in Chile. They emerged in early 1891. Some cement companies and business houses include Williamson, Balfour \& Co (Fagalde, 2011), which negotiates white cement and was supposedly world renowned as the best cement plant; Graham Rowe \& Co., who worked with Portland cement; Swinglehurts \& Co., which sold Portland cement; Lazonby \& Co., which imported "The Two Americas" cement; and 
Swedish-Chilean Holmgres Bros. \& Co., which imported Portland cement and "Saylor." As for domestic industries involved in the extraction of lime and cement production, Portland Cement Co. of La Calera (founded in 1891) is one of the oldest, Melon was used from 1906 onwards, and Polpaico was established in 1945. Melon extracts the raw material in the former estate of the same name in the province of Quillota. The material is processed in the Calera factory, in which cement is also produced (Greve, 1944). In 1910 production was in the air, and in 1925 this industry was considered the most important in the country and one of the largest in South America (CPA, 1925). Similarly, the sand used for construction was extracted from the surrounding area (Valparaiso and Viña del Mar) and from Las Delicias estuary (now Argentina Ave), Marga-Marga, and Jaime estuary (now France Ave). They utilized riverbeds with a high concentration of organic materials because of the urban conditions (Henriquez, 1907).

\section{Results}

Integrating historical research, comparisons with other buildings by the same architect, and on-the-ground surveys of construction characteristics and structural criteria considered by architect-engineer $\mathrm{E}$. O. Harrington in designing the Hotel Royal is obtained.

\section{Foundations}

The building has a stone- and lime-mortar basement on the perimeter and interior transversal main walls. The width is variable, but it is verified that the site has an average width of $100 \mathrm{~cm}$. Its width and shape vary for the perimeter and interior walls (Figure 5).
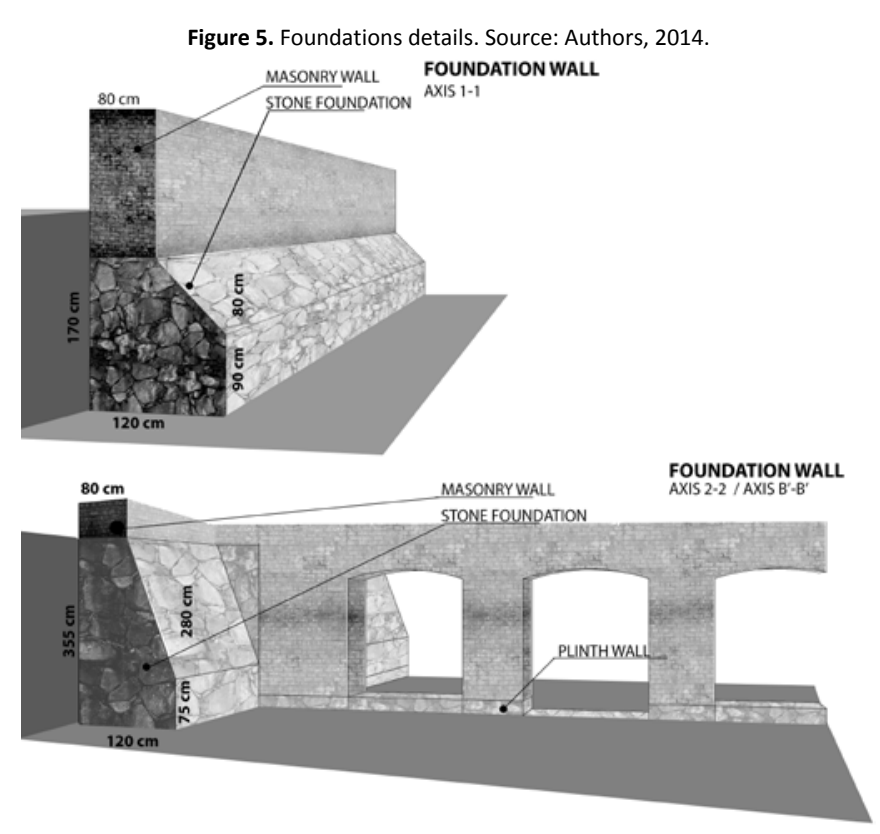

\section{Main Vertical Structure}

On the first floor and on the upper floors (except for the attic), the perimeter walls are made of brick masonry in variable widths, decreasing $10 \mathrm{~cm}$ from floor to floor: $80 \mathrm{~cm}$ on the first floor, $70 \mathrm{~cm}$ on the second floor, and $60 \mathrm{~cm}$ in the third floor. By contrast, the transverse walls were erected as firewalls, and surpass the attic in width (Axles A, B, C, $D, E$, and F). They were also built in variable sections. The registered field dimensions are as follows: $80 \mathrm{~cm}$ in the basement, $60 \mathrm{~cm}$ on the first floor, $50 \mathrm{~cm}$ on the second and third floors, and approximately $40 \mathrm{~cm}$ on the fourth floor. The decrease in thickness in the upper floors of the building contribute to its reduced seismic risk. As for the basement's pillars, they are $100 \times 80 \mathrm{~cm}$ at their widest and are spaced on average $3.1 \mathrm{~m}$ from each other. On the first floor (commercial floor), iron columns are built, which are $20 \mathrm{~cm}$ in diameter and spaced $3.1 \mathrm{~m}$ from each other.

\section{Bonding}

The dimension of the brick unit mainly used is $38 \times 19.5 \times 6 \mathrm{~cm}$, and sometimes the link header is $38 \times 10 \times 6 \mathrm{~cm}$; all are joined by lime mortar. Typologies binding were mostly found in stretcher bond and the head; however, a variation between the walls and columns in the basement (Figure 6) was also found. 
Inner masonry column

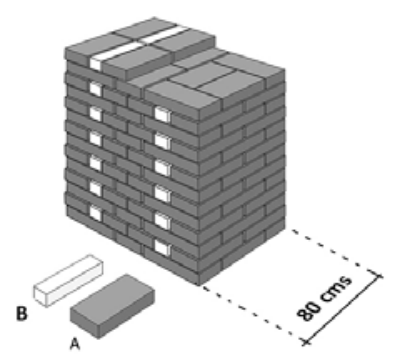

A. BRICK $38 \times 19.5 \times 6 \mathrm{cms}$

B. BRICK $38 \times 10 \times 6 \mathrm{cms}$
Inner masonry wall

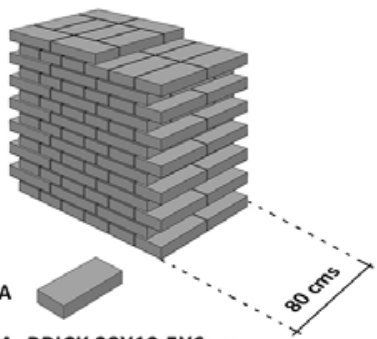

A. BRICK $38 \times 19.5 \times 6 \mathrm{cms}$

\section{Mezzanine structure}

In the building, two structures are identified as being used for mezzanines: iron beams with brick vaults, and wooden beams. The first is used in the basement and on the first floor. This is configured in iron beams of double T-shaped 40 $x 15.5 \mathrm{~cm}$ beams at $6 \mathrm{~mm}$ thick, and they are arranged every 3 or $3.5 \mathrm{~m}$ with the axis above the columns of iron or brick masonry (depending on level in the longitudinal direction of the building). On top of these structural beams, iron double T-shaped beams are placed in the shortest dimension of $22 \times 12.5 \mathrm{~cm}$ and $4 \mathrm{~mm}$ thick, and they are arranged $100 \mathrm{~cm}$ from each other in the axis average transverse direction of the building. Brick vaults were placed in the space $100 \mathrm{~cm}$ between the joists. The beams were embedded in the walls and pillars of brick masonry, leaving a space at the junction for mounting the beam. The resulting gaps are filled again with brick. This slab was covered with ceramic or wood in order to obtain the finished floor (Figure 7).

Figure 7. Mezzanine detail. Source: Authors, 2014.

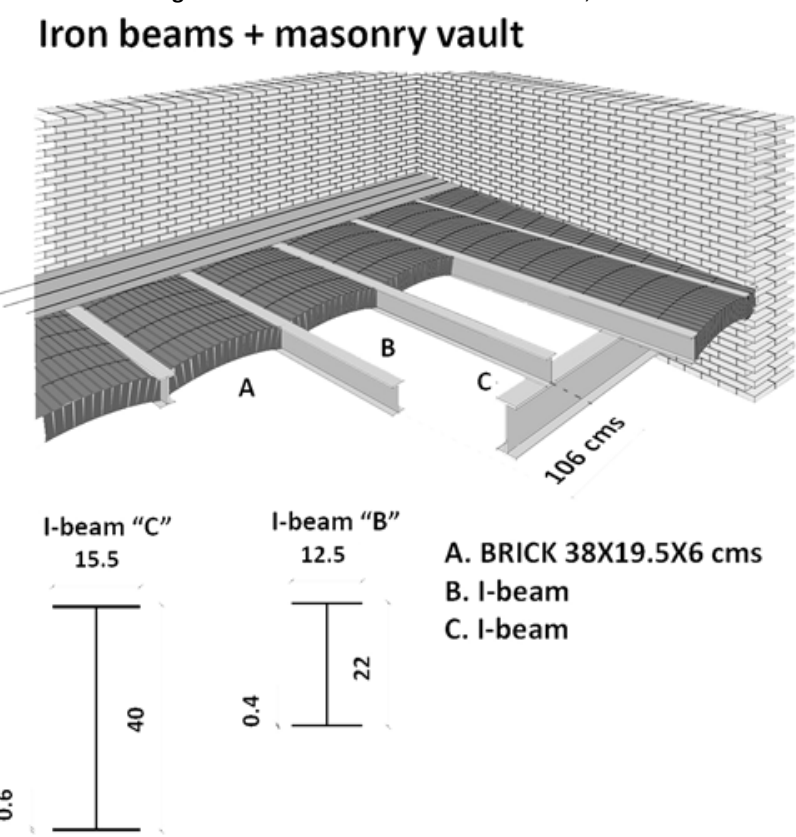

In the other mezzanines, a wooden structure was built. This was made of oak beams 12 "x 4" and 12 "x 8", with $55 \mathrm{~cm}$ separation between the axles and in the longitudinal direction of the building. The beams were recessed to the brick masonry wall, placing a metal plate on the upper and lower sides of the beam, and the latter was tied to the brick masonry. Furthermore, the beams were placed on a wooden template, which was internally delimited by the walls and placed along the surface of the beams. Both the floor and ceiling in this structure were covered with parquet fact coigüe 11/2 "x 4". 


\section{Partition walls}

From the second floor on there are wooden partitions forming the inner divisions. These frames are filled with adobe and mud plaster on wooden slats. For walls, oak was used and varied in the following dimensions: 6 "x 6", 5 "x 5", and 4 "x 4". It is worth mentioning that the internal height of the floors exceeds $4 \mathrm{~m}$, which influences the partition wall structures. These interior walls were built on top and bottom sills, diagonal braces, and struts. The latter were prepared in 60- to 70-cm axes; bracing diagonals were placed at the ends of the partition walls, and on the sides of the openings (such as doors and windows) in order to avoid potential deformation. At crossings with studs, diagonal bracings prevailed. The coating was performed on a wooden tablet with horizontal slats 1 "x $1 / 2$ " spaced 1 "apart. The plaster is made of clay with a lime finish.

\section{Facade configuration}

In order to build the openings, both for facades and as interior brick walls, different types of brick arches were built. Brick masonry in general involves two bundles of regular bricks-forming the width of the wall-and bricks bound in mid-header to finish and give continuity to the walls when there is an opening. The flattened arc, the arc midpoint, and the arch and three types of bows found for construction openings. The former is used in openings, in the basement, and in the first and second floors (it was also found in the upper joint of the brick columns placed in the basement as a beam in order to distribute the weight). The arc is the midpoint and is used on the facades of the first, second, and third floors. Finally, the lowered arches are used to deliver the weight from the first floor to the pillar in the basement, which were arranged approximately every $3.3 \mathrm{~m}$ wheelbase, and also placed in some of the inner walls (Figure 7).

\section{Structural conception}

For this concept, it is worth noting that earthquakes occurring in 1906, 1985, and 2010 destroyed many historic buildings in the city with similar characteristics to Harrington's building. This confirms Harrington's empirical and theoretical knowledge in the field of construction. Some of the key elements that support this are the inner seismic resistance perpendicular axes that bound the perimeter system ( $A x e s A, B, C, D, E$, and F). These axes are at distances of 29 and $11 \mathrm{~m}$ apart, and also have structural continuity at all levels. Furthermore, the floor structures, especially iron, can configure a diaphragm to stiffen the system and contribute to the interconnection of the vertical elements. The decrease in thickness in all the brick walls is another feature to pay attention to, especially given the continuous lightening weight gained in the upper floors as well as the wooden walls applied in these plants. Our hypothesiswhich could not be proven without non-destructive testing-is that the brickwork has iron-reinforcing elements inside. This technology was utilized in those years in Chile as explained, and was employed in construction, as seen in some historical photos. While most of these structural criteria are already known today, it is important to highlight the historical context in which they are used with the materials described and the specific architectural typologies they meet. Again, the 1906 earthquake records compare outturns of buildings that appear to be very similar in materiality and form.

The technological process experienced in the port city of Valparaiso is part of the industrial, cultural, socioeconomic, and architectural trend, illustrating all together the successful conduct of the city in those years, especially as the main port city of Chile and one of the most important cities in the South Pacific. The industrialization and its impact on growth and modernization in the port city of Valparaiso, helped out by the economic boom illustrated in the city's infrastructure, equipment, and even in dwellings, make Valparaiso a centre of prime importance internationally. The construction industry meanwhile advances in its effort to meet the needs created by the city for its growth as well as the architectural and urban development of Valparaiso. Moreover, this new technological approach benefited from the arrival of new materials such as iron and wood, which were incorporated into new construction methods. These technologies are undergoing a process of adaptation, especially taking into account factors such as topography, availability of materials, and the fight against frequent earthquakes.

In addition, the aftermath of the 1906 earthquake deeply affected Valparaiso's local society, because after this catastrophe, the construction professionals needed to rethink building methods, thus improving the structural strength of brick masonry construction. Brick masonry remained a widely used technique, but with improvements in structural design. In this context, the work of E. O. Harrington represents the connection to the structural and 
constructive principles of an era, with the merit of being perfectly adapted to local conditions. Factors such as the regularity of the structural matrix (based on the distance between structural perpendicular axes); soil consistency; joint technique between different materials (iron, brick, wood, and stone, working in a mixed structural system); lightening of the structure in upper floors; and diaphragms tying the whole system together based on the requirements of each level and height make the Royal Hotel a prime building representative of its time.

Chávez, J., Álvarez, O. (2005). Metodología para el diagnóstico y restauración de edificaciones. Revista de la Construcción, vol. 4(2), 47-54.

Consejo de Monumentos Nacionales. (2001). Postulación de Valparaíso como Sitio del Patrimonio Mundial / UNESCO. Santiago: Productora Gráfica Andros Ltda.

LA UNIÓN (1899) Explotación de una cantera, retrieved from LA UNIÓN (January 24), p. 4.

Fagalde, A. (2011). El puerto de Valparaíso y sus obras de mejoramiento. Santiago de Chile: Cámara Chilena de la Construcción. Pontificia Universidad Católica de Chile. Dirección de Bibliotecas Archivos y Museos.

Greve, E. (1944). Historia de la Ingeniería en Chile. Tomo III. Santiago: Imprenta Universitaria.

Henríquez, H. (1907). El terremoto de Valparaíso bajo su aspecto constructivo. Valparaíso: s.n.

León, S. (2008). Los antiguos hoteles del puerto de Valparaíso: 1887-1927. Valparaíso: Imprenta Libra.

Miranda, R. (1903). Manual de Edificación Chilena. Santiago: Compañía de Tipos Norte Americana.

CPA (1925). Reseña del segundo Congreso Panamericano de Arquitectos: Documentos, actas, comunicaciones y discursos. Santiago: Imp. Universo.

Saragoni, R., Carvajal, Á. (1989). Estudio Comparativo de los terremotos de Valparaíso de 1906 y 1985. En 5as. Jornadas Chilenas de Sismología e Ingeniería Antisísmica (Vol. 1, pp. 345-356). Santiago: Ministerio de Vivienda y Urbanismo.

Silva, V. (1910). Monografía histórica de Valparaíso: Desde su descubrimiento hasta nuestros días 1536-1910. Valparaíso: Imprenta Moderna.

SOFOFA. (1896). Estadística de las Industrias del Departamento de Valparaíso. Boletín de la Estadística Industrial de la República de Chile 1894-1895, $4,48-63$.

Ugarte, J. (1910). Valparaíso: 1536-1910. Recopilación histórica, comercial y social. Valparaíso: Imprenta Minerva.

Vásquez, N. (1999). Cartografía histórica de Valparaíso. Valparaíso: Ediciones Universitarias de Valparaíso de la Universidad Católica de Valparaíso.

Vergara, M. (2010). Actualización y complementación de la zonificación de los suelos de fundación sector plan de Valparaíso. Undergraduate Thesis, Universidad de Valparaíso, Valparaíso.

Waisberg, M. (1988). La vivienda de fines del siglo XIX en Valparaíso: Casas de Playa Ancha (2a. ed.). Santiago: Fondo Nacional de Desarrollo Científico y Tecnológico. 